\title{
Expression Patterns of Defense-Related Genes in Different Types of Arbuscular Mycorrhizal Development in Wild-Type and Mycorrhiza-Defective Mutant Tomato
}

\author{
Ling-Ling Gao, ${ }^{1}$ Wolfgang Knogge, ${ }^{2}$ Gabriele Delp, ${ }^{3}$ F. Andrew Smith, ${ }^{1}$ and Sally E. Smith ${ }^{1}$ \\ ${ }^{1}$ Soil and Land Systems, School of Earth and Environmental Sciences and ${ }^{2}$ Plant and Pest Science, School of Agriculture \\ and Wine, Waite Campus, The University of Adelaide, Adelaide, 5005, Australia; ${ }^{3}$ Department of Natural Sciences, \\ Södertörns University College, S-14189 Huddinge, Sweden
}

Submitted 26 January 2004. Accepted 23 June 2004.

\begin{abstract}
The expression of defense-related genes was analyzed in the interactions of six arbuscular mycorrhizal (AM) fungi with the roots of wild-type tomato (Lycopersicon esculentum Mill.) cv. 76R and of the near-isogenic mycorrhiza-defective mutant $r m c$. Depending on the fungal species, wild-type tomato forms both major morphological AM types, Arum and Paris. The mutant rmc blocks the penetration of the root surface or invasion of the root cortex by most species of AM fungi, but one fungus has been shown to develop normal mycorrhizas. In the wild-type tomato, accumulation of mRNA representing a number of defense-related genes was low in Arum-type interactions, consistent with findings for this AM morphotype in other plant species. In contrast, Paris-type colonization, particularly by members of the family Gigasporaceae, was accompanied by a substantial transient increase in expression of some defenserelated genes. However, the extent of root colonization did not differ significantly in the two wild-type AM morphotypes, suggesting that accumulation of defense gene products per se does not limit mycorrhiza development. In the mutant, interactions in which the fungus failed to penetrate the root lacked significant accumulation of defense gene mRNAs. However, phenotypes in which the fungus penetrated epidermal or hypodermal cells were associated with an enhanced and more prolonged gene expression. These results are discussed in relation to the mechanisms that may underlie the specificity of the interactions between AM fungi and the rmc mutant.
\end{abstract}

Additional keywords: Arum- and Paris-type mycorrhizas, defense responses.

In nature, the majority of land plants are hosts to arbuscular mycorrhizal (AM) fungi, which form long-term, biotrophic, compatible symbioses that are usually beneficial. The main basis for mutualism is the reciprocal transfer of nutrients

Current address for Ling-Ling Gao: CSIRO Plant Industry, Private Bag 5, Wembley, WA, 6913, Australia.

Current address for Wolfgang Knogge: Institute for Plant Biochemistry, Department of Stress and Developmental Biology, Weinberg 3, D-06120, Halle/Saale, Germany.

Corresponding author: Sally E. Smith; E-mail: sally.smith@adelaide.edu.au between the partners, sugars from plant to fungus and mineral nutrients, particularly phosphate $(\mathrm{P})$, from fungus to plant (Smith and Read 1997). Other benefits of the symbiosis to the plants include improved water relations and tolerance to some plant diseases (Newsham et al. 1995). The fungus-plant interactions are generally thought to have low specificity, although recent work indicates that some plants and fungi may have a restricted suite of potential partners (Helgason et al. 2002; Sanders 2002).

Typical AM colonization involves formation of appressoria on the root epidermis, penetration of the epidermal cells, and extensive fungal growth within the root cortex, which can follow two main developmental patterns - the Arum type and the Paris type (Smith and Smith 1997). In the former, fungal hyphae grow in the intercellular spaces between root cortical cells, and from there, they branch off and penetrate cells to differentiate much-branched, terminal arbuscules. Usually there is a single hyphal penetration per arbuscule-containing cell. In Paris-type AM, hyphae (sometimes several per cell) grow directly from cell to cell so that the intercellular phase of development is highly restricted or completely absent. Fungal penetration of plant cell walls is therefore much more frequent in Paris-type than in Arum-type AM. Complex coils develop within colonized cells of Paris-type AM, which may bear arbuscule-like branches (arbusculate coils). At no stage in either morphotype is the plant plasma membrane penetrated by fungal hyphae, and all phases of fungal development (intercellular hyphae, arbuscules, coils, and arbusculate coils) remain in an apoplastic compartment outside the plant protoplast.

Expression of plant defense-related genes has previously only been investigated in Arum-type AM (see Harrison 1999). In these, as in other compatible biotrophic interactions, the defense response appears weak and occurs transitorily during the early phases of colonization. Localized expression of defenserelated genes or accumulation of gene products in arbusculecontaining cells has been observed and may be related to invasion of the cells (e.g., Bonanomi et al. 2001; Harrison and Dixon 1994). By the time the mycorrhizal fungi are well established in the roots, responses are often similar to or lower than those in nonmycorrhizal control plants, suggesting that the suppression of plant defense responses may contribute to successful, compatible AM fungal colonization (Garcia-Garrido and Ocampo 2002; Gianinazzi-Pearson et al. 1996; Harrison 1999). Confirmation of this hypothesis has been difficult because there are few examples of naturally occurring, incom- 
patible interactions between AM fungi and nonhost plant species that are closely related to normal AM hosts. In fact, exclusion of AM fungi is usually common to all members of major, nonhost taxa, such as the Brassicaceae and Caryophyllaceae (Gianinazzi-Pearson 1984), so that comparisons have had to be made between distantly related taxa. However, mutants of AM host plants that block fungal development at various stages of root colonization are increasingly being identified, and these provide good comparative material for investigation of mechanisms that facilitate or restrict symbiotic development (Barker et al. 2002; Marsh and Schultze 2001; Peterson and Guinel 2000).

Most information on defense-related reactions in AM-defective mutants has been obtained from legumes, such as Pisum, Medicago, and Lotus spp. in which symbioses with both AM fungi and rhizobia are defective. In these, normal (Arum-type) interactions are characterized by weak or suppressed defense responses. In contrast, responses in mutants appear stronger and involve changes at several different levels, including increased production of the signaling compound salicylic acid (Blilou et al. 1999), expression of defense-related genes (Harrison and Dixon 1993; Ruiz-Lozano et al. 1999), and accumulation of defense-associated proteins (Dumas-Gaudot et al. 1994) or phytoalexins (Blilou et al. 1999; Morandi et al. 2002). Cytological studies have identified cell wall appositions on the inner face of root cell walls adjacent to the appressoria of pea mutants (Gollotte et al. 1993) and death of invaded epidermal cells of Lotus mutants (Bonfante et al. 2000). The changes suggest that plant defense mechanisms may be involved in restricting colonization in mutants, but as yet, no clear integrative model has emerged.

The mutants in tomato (the only nonlegume mutants identified so far) have not previously been used to investigate defense responses to mycorrhizal colonization. Two of these (M161 and M20) (David-Schwartz et al. 2001, 2003) are impaired in their ability to support preinfection steps (pmi) and, in consequence, are unlikely to involve plant defense responses. In the work re-

Table 1. Mycorrhizal colonization phenotypes in the interactions between the arbuscular mycorrhizal (AM) fungi used and wild-type (76R) and mycorrhiza-defective mutant $(r m c)$ tomato $^{\mathrm{a}}$

\begin{tabular}{lcc}
\hline & \multicolumn{2}{c}{ AM phenotypes } \\
\cline { 2 - 3 } Fungal species & Wild-type 76R & Mutant $\boldsymbol{r m c}$ \\
\hline Glomus intraradices & Arum-type & $\mathrm{Pen}^{-\mathrm{b}}$ \\
G. mosseae & Arum-type & $\mathrm{Coi}^{-\mathrm{c}}$ \\
G. coronatum & Paris-type & $\mathrm{Coi}^{-}$ \\
Gigaspora margarita & Paris-type & $\mathrm{Coi}$ \\
Scutellospora calospora & Paris-type & $\mathrm{Coi}^{-}$ \\
Glomus sp. WFVAM23 & Arum-type & $\mathrm{Myc}^{+\mathrm{d}}$ \\
\hline
\end{tabular}

${ }^{a}$ Further details are available in Gao et al. 2001.

${ }^{\mathrm{b}}$ Mutant blocks fungal penetration.

${ }^{\mathrm{c}}$ Mutant blocks invasion of the root cortex, but fungi form normal appressoria followed by penetration of epidermal and hypodermal cells.

${ }^{\mathrm{d}}$ Mutant shows swollen penetration structures but relatively normal, although slower cortical colonization. ported here, we used wild-type tomato (Lycopersicon esculentum Mill. cv. Rio Grande 76R) and a near-isogenic mutant with reduced mycorrhizal colonization ( $r m c)$ (Barker et al. 1998). The wild type forms both Arum- and Paris-type AM, depending on the fungal species (Cavagnaro et al. 2001). The recessive mutation $r m c$ confers different levels of 'resistance' to different AM fungi, and three major mutant phenotypes have been observed (Table 1) (Gao et al. 2001). Glomus intraradices is blocked at the root surface, thus yielding a $\mathrm{Pen}^{-}$phenotype. Four fungal species were able to penetrate the epidermal and hypodermal cell layers but were unable to colonize the root cortex (Coi ${ }^{-}$phenotype). One Glomus sp. (WFVAM23, formerly called G. versiforme) (Cavagnaro et al. 2001; Gao et al. 2001) forms abnormal appressoria on contact with the roots of the mutant and is slow to penetrate the epidermis, but once inside the root, cortical colonization is rapid and normal, including both arbuscules and vesicles (Gao et al. 2001). External mycelium is produced, and the Arum-type mycorrhiza is physiologically similar to the wild type with respect to $\mathrm{P}$ transfer to the plants (K. Poulsen, L.-L. Gao, S. E. Smith, F. A. Smith, and I. Jakobsen, unpublished data). We designate this interaction " $\mathrm{Myc}^{+}$." There was an indication that fungi forming Paris AM in wild-type tomato also produced the $\mathrm{Coi}^{-}$phenotype in the mutant, whereas fungi forming Arum AM produced several different mutant phenotypes (Table 1) (Cavagnaro et al. 2001; Gao et al. 2001). However, a much larger number of fungi need to be screened before this trend can be confirmed. Thus, wild-type tomato and $r m c$ mutant provide a range of mycorrhizal phenotypes for comparative studies that is not available in other plant species. We were therefore able to address several different questions concerning the involvement of plant defense-related reactions in AM interactions in both wild-type and mutant plants. i) Is the expression of defense-related genes similar in Arum- and Paris-type mycorrhizas formed in wild-type tomato? ii) Are there differences in the expression of defense-related genes between wild-type and mutant tomato in response to AM fungal inoculation? iii) If so, are such differences correlated with blocks at different steps in the colonization of the mutant by different fungal species or with other features of the different interactions?

\section{RESULTS}

\section{Mycorrhizal colonization phenotypes and transcript accumulation of defense-related genes.}

In a previous study (Cavagnaro et al. 2001; Gao et al. 2001), the interactions of six species of AM fungi with both wild-type (76R) and mutant $(\mathrm{rmc})$ tomato (Barker et al. 1998) were analyzed. In roots of wild-type plants both AM morphotypes were formed, depending on the fungal species. Furthermore, there was variation in the phenotypes obtained on the mutant tomato (Table 1). The interactions analyzed in the previous study were used to obtain a preliminary indication about the role of the tomato defense response during mycorrhizal colonization, in particular during the inhibited development in the mutant. For this purpose, the expression

Table 2. cDNA probes used in expression analysis of defense-related genes in tomato wild type (76R) and a mycorrhiza-defective mutant ( $r m c$ ) in response to mycorrhizal colonization

\begin{tabular}{|c|c|c|c|c|}
\hline Gene product & cDNA & Accession No. & Insert size (bp) & Reference \\
\hline Extracellular PR-1 protein & $P R-1$ & M69248 & 763 & van Kan et al. 1992 \\
\hline Extracellular acidic $\beta$-1,3-glucanase & GluAC & M80604 & 1,189 & van Kan et al. 1992 \\
\hline Intracellular basic $\beta$-1,3-glucanase & GluBAS & M80608 & 1,331 & van Kan et al. 1992 \\
\hline Extracellular acidic chitinase & Chi3 & Z15141 & 942 & Danhash et al. 1993 \\
\hline Intracellular basic chitinase & Chi9 & Z15140 & 1,108 & Danhash et al. 1993 \\
\hline Phenylalanine ammonia-lysase & PAL5 & M90692 & 580 & Lee et al. 1992 \\
\hline
\end{tabular}


of several defense-related genes (Table 2) was analyzed six weeks after inoculation, i.e., at a relatively late stage of mycorrhizal development in wild-type plants and after completion of the mutant phenotypes on the mutant plants. The six genes encode pathogenesis-related protein 1 (PR-1), extracellular acidic $\beta-1,3$ glucanase (GluAC), intracellular basic $\beta-1,3$ glucanase (GluBAS), extracellular acidic chitinase (Chi3), intracellular basic chitinase (Chi9), and phenylalanine ammonialyase (PAL5). In this experiment, no differences in expression of either Chi9 or PAL5 were observed (results not shown). In wild-type interactions, expression levels of the other four genes varied with AM fungal species. The transcript levels of $P R-1, G l u B A S$, GluAC, and Chi3 tended to be low in association with $G$. intraradices, intermediate with $G$. mosseae, Glomus sp. WFVAM23, and G. coronatum, and highest with the two members of the family Gigasporaceae, Gigaspora margarita and Scutellospora calospora (Fig. 1). In the mutant, transcript levels of $P R-1$, Chi3, and, for some interactions, GluBAS were higher than in wild-type plants. This increase appeared to be associated with the $\mathrm{Coi}^{-}$phenotype but was again particularly apparent with members of the family $\mathrm{Gi}_{-}$ gasporaceae (Table 1; Fig. 1), so at this stage, it is not possible to determine if differences are related to mutant phenotype or phylogenetic relationships of the fungi.

\section{Timing of fungal colonization}

\section{of wild-type and mutant root tissues.}

In order to assess further the possible role of the plant defense in blocking mycorrhiza development of the mutant tomato, the timing of fungal development in wild-type tomato and $r m c$ mutant was compared with that of the expression of the six defense-related genes. Three fungal species were selected for this detailed analysis: $G$. intraradices (Arum-type AM, Pen ${ }^{-}$mutant phenotype), S. calospora (Paris type, Coi ${ }^{-}$) and Glomus sp. WFVAM23 (Arum type, $\mathrm{Myc}^{+}$).
In wild-type tomato, colonization of the root epidermis by all fungi was first observed 4 days after transplantation into the nurse pots and was followed by rapid colonization of the root cortex by 8 days (Fig. 2A and B). The total root length colonized increased dramatically by 12 days and reached a plateau at 18 days for all fungal species (Fig. 2C). As expected, the root cortex was the major site of fungal development, including intercellular hyphae and either arbuscules or vesicles, or both, for the Glomus species and intracellular hyphal coils and arbusculate coils for $S$. calospora. Arbuscules or arbusculate coils were observed as soon as the fungal hyphae penetrated the root cortical cells (8 days). Values for percentage of the root length containing arbuscules or arbusculate coils were very similar to total percent cortical colonization for all interactions; only the latter are shown in Figure 2B. Glomus sp. WFVAM23 grew slightly more rapidly than the other two fungi, and between 12 and 24 days, it had colonized a significantly $(P<0.01)$ higher percentage of the root length than did $G$. intraradices or $S$. calospora. By 42 days however, all three fungi had colonized $>70 \%$ of the root length, and colonization percentages were not significantly $(P>0.05)$ different between fungi.

Colonization of the $r m c$ mutant varied between fungal species, particularly with respect to penetration of the different root cell layers, as previously observed (Gao et al. 2001). The development of $G$. intraradices was arrested on the root surface $\left(\mathrm{Pen}^{-}\right)$; epidermal colonization was low (Fig. 2A), and very low cortical colonization (approximately $10 \%$ of root length, including arbuscules and vesicles) had developed by 42 days (Fig. 2B and C). S. calospora frequently penetrated the root epidermis, but fungal hyphae remained confined within one or a few adjacent epidermal or hypodermal cells (Fig. 2A) (Gao et al. 2001); colonization of cortical cells and formation of arbusculate coils was never observed ( $\left.\mathrm{Coi}^{-}\right)$(Fig. 2B). As in the wild-type plants, colonization of the $r m c$ mutant reached a plateau at 18 days, when approximately $30 \%$ of the total root

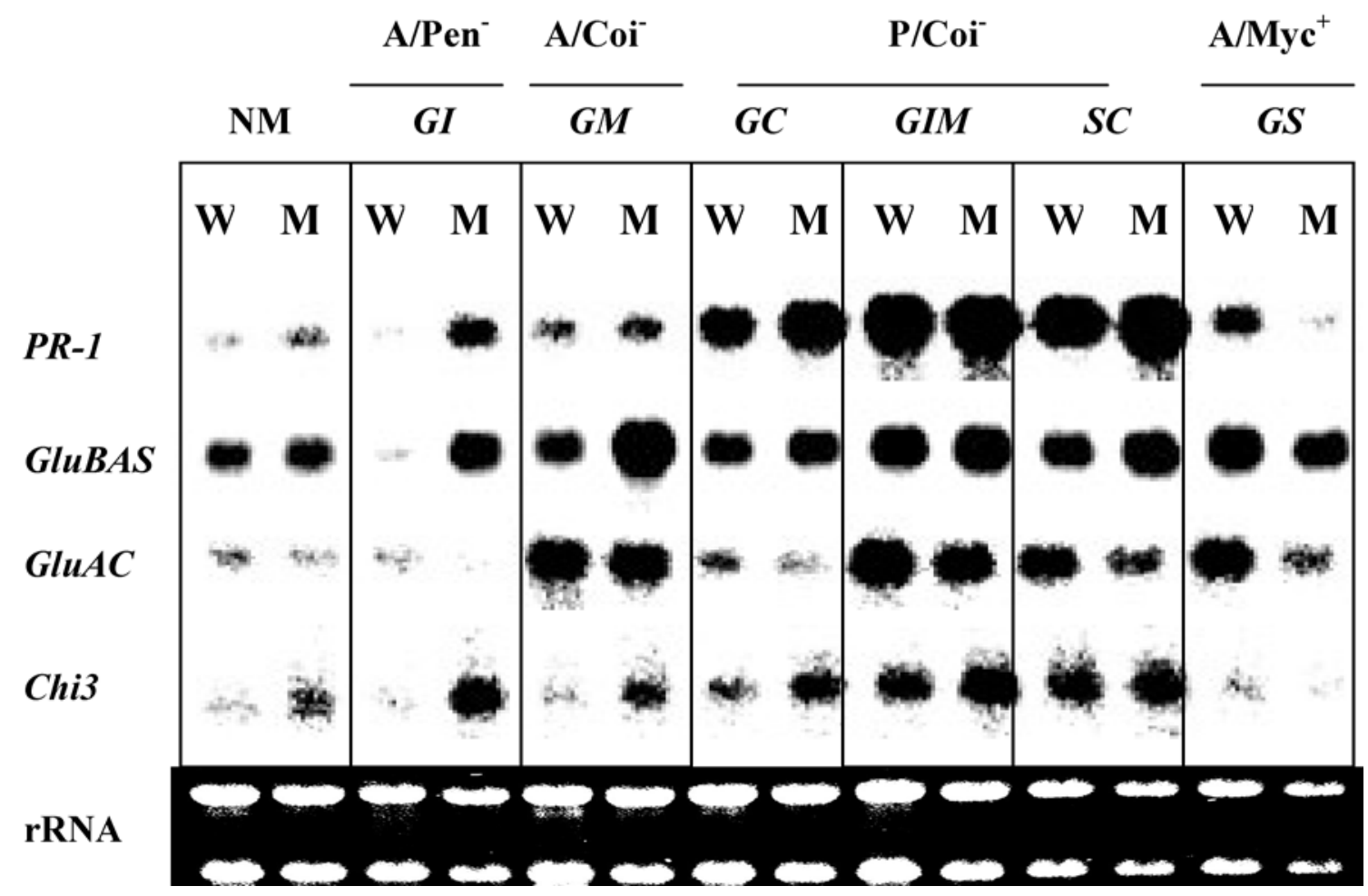

Fig. 1. Accumulation of mRNAs from four defense-related genes 6 weeks after inoculation of wild-type (W) and $r m c$ mutant (M) tomato plants with different arbuscular mycorrhizal (AM) fungi. GI = Glomus intraradices; GM=Glomus mosseae $;$ GC = Glomus coronatum; GIM = Gigaspora margarita; SC = Scutellospora calospora; $G S=$ Glomus sp. WFVAM23; NM = mock-inoculated controls. Ethidium bromide-stained rRNA was used as references for equal loading. A and $\mathrm{P}$ indicate Arum- and Paris-type mycorrhiza formed in wild-type tomato. $\mathrm{Pen}^{-}, \mathrm{Coi}^{-}$, or $\mathrm{Myc}^{+}$indicate the mutant phenotype formed in the tomato rmc line. 
length showed epidermal or hypodermal colonization only (Fig. 2A, B, and C). In contrast, colonization of the mutant by Glomus sp. WFVAM23 was rapid and similar to the wild-type interaction. At 4 days, the percentage of root length showing epidermal colonization was higher than with the other fungi (Fig. 2A). By 8 days, epidermal colonization was much higher than in any other interaction and the total root length colonized exceeded even that in the wild type (Fig. 2C). However, most of the fungal development remained confined to the root epidermis at this stage, and extensive colonization of root cortex and formation of arbuscules did not occur until 12 days (4 days later than in the wild-type). The maximum values for cortical and total colonization of the mutant by Glomus sp. WFVAM23 were approximately 25 and 35\%, respectively (i.e., in both cases lower than in the wild-type) (Fig. 2B and C). As in the wild-type interactions, most cortical colonization included arbuscules, with or without vesicles.

\section{Expression of defense-related genes} in nonmycorrhizal tomato plants.

Before transplanting seedlings of wild-type tomato and $r m c$ mutant to nurse pots, there were no significant differ- ences between wild type and mutant in mRNA accumulation for any of the six defense-related genes $(P>0.05)$ (results not shown). After transplantation to nonmycorrhizal nurse pots, trends were generally similar in both genotypes with $P R-1$ and Chi3 showing higher transcript accumulation in both plant genotypes at 42 days (results not shown). These results suggest that the $r m c$ mutation has little or no effect on the expression of defense-related genes in the absence of fungal invasion.

\section{Expression of defense-related genes in tomato plants inoculated with AM fungi.}

Wild-type tomato. When the wild-type tomato plants were colonized by AM fungi, the accumulation of transcripts from defense-related genes varied with fungal species (and hence with AM morphotype) and stage of fungal colonization (all at $P<0.01$ ). In the Paris-type interaction with $S$. calospora (Fig. 3 ), accumulation of all six mRNA species was transiently induced upon colonization. Maximum expression of most genes correlated with the fungal invasion of the root cortex between 8 and 18 days. However, the magnitude of the increase varied with the genes. While $P R-1, G l u B A S$, and GluAC mRNAs ac-
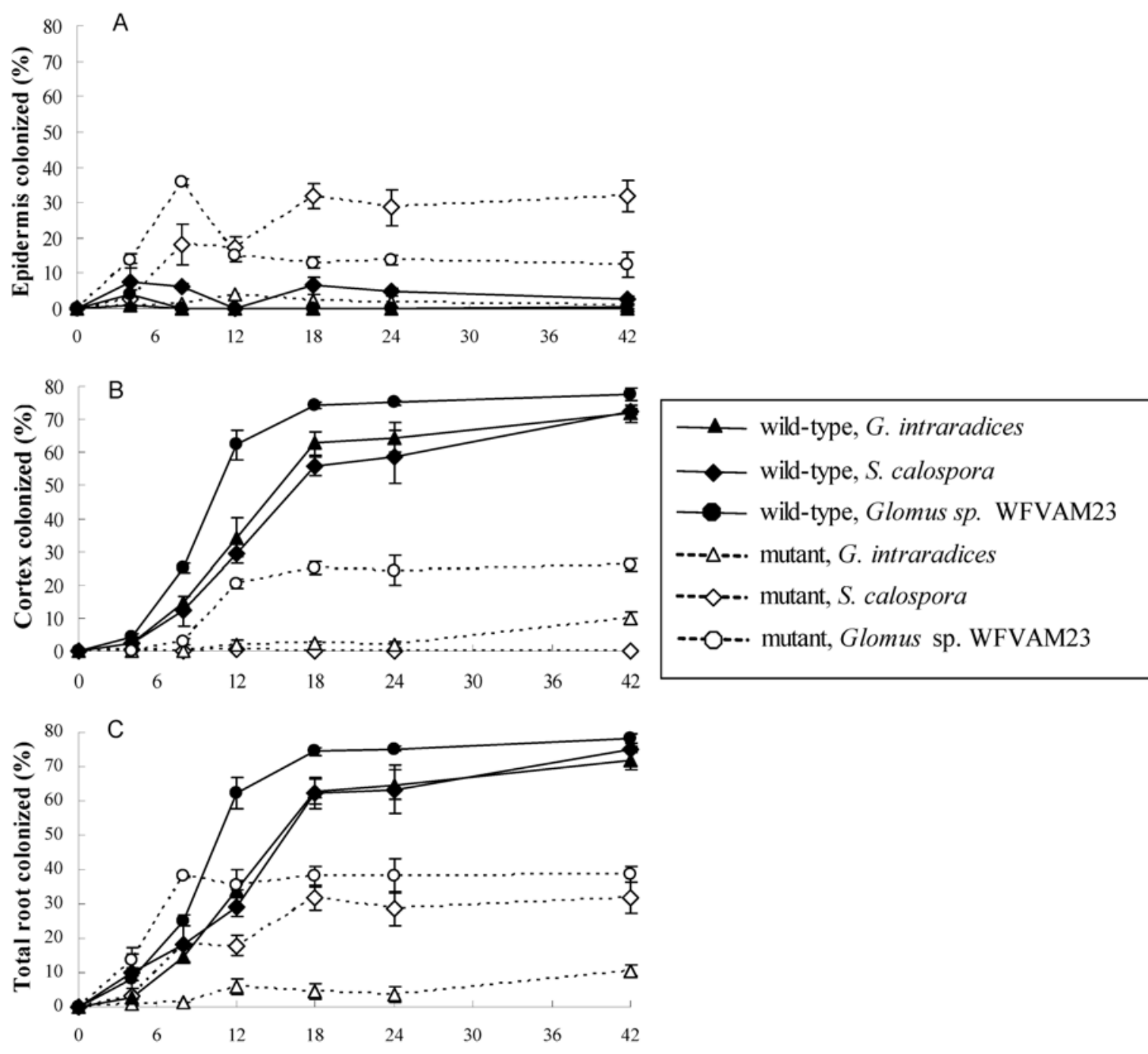

Days after inoculation

Fig. 2. Colonization of root tissues of wild-type tomato and of $r m c$ mutant by Glomus intraradices, Scutellospora calospora, and Glomus sp. WFVAM23. A, Fungal hyphae colonizing only the root epidermis (no colonization of inner cell layers). B, Cortical colonization, including intercellular hyphae and arbuscules or arbusculate coils (S. calospora only) and vesicles (Glomus spp. only). C, Total root length colonized (all cell types). Values are means and standard errors of means of three replicate pots. 
cumulated to high levels (approximately six- to eightfold over mock-inoculated plants) (Fig. 3A, B, and C), Chi3, Chi9, and PAL5 mRNAs accumulated to a lesser extent (approximately two- to threefold) (Fig. 3C, D, and E). After 24 days, the levels of all six mRNAs declined to values at or below those of noninoculated control plants.

In contrast to the Paris-type AM formed by S. calospora, a strong induction of defense-related genes was not typical for the Arum-type AM formed by $G$. intraradices and Glomus sp. WFVAM23 (Figs. 4 and 5). In the interaction with $G$. intraradices, accumulation of $P R-1$, GluAC, and Chi9 mRNAs increased slightly, reaching levels of only approximately 1.5 to 2 times those of mock-inoculated control plants. The increase occurred during the early stage of fungal colonization of the root cortex at 8 or 12 days (Fig. 4A, C and E). At 42 days, mRNA concentrations were at or below those of noninoculated control plants, whereas the expression of GluBAS, Chi3, and PAL5 was never significantly induced. The colonization of wild-type tomato roots by Glomus sp. WFVAM23 was characterized by a transient, three- to fourfold increase of Chi3 mRNA over that of mock-inoculated plants at 12 days (Fig. 5D). In contrast, expression of the other genes analyzed was not significantly induced. As with $G$. intraradices, the mRNA levels of the six genes were at or below those of noninoculated control plants at 42 days (Fig. 5). These results are in agreement with the preliminary data (Fig. 1), demonstrating, particularly during early stages of the interaction, a generally higher accumulation of defense-related gene transcripts in Paris-type AM formed by $S$. calospora, as compared with Arum-type AM formed by the two Glomus species.

rmc mutant. In the $r m c$ mutant, the accumulation of defense-related gene transcripts in response to inoculation with AM fungi again varied with fungal species. With $S$. calospora (Coi ${ }^{-}$mutant phenotype with extensive colonization of root epidermis and multiple cell penetrations) substantial increases (three- to eightfold) in mRNA accumulation occurred for most genes between 8 and 18 days (Fig. 3). Expression of $P R$ 1, GluBAS, GluAC, and Chi9 tended to be more prolonged than in the wild type and remained high even at 42 days (Fig.
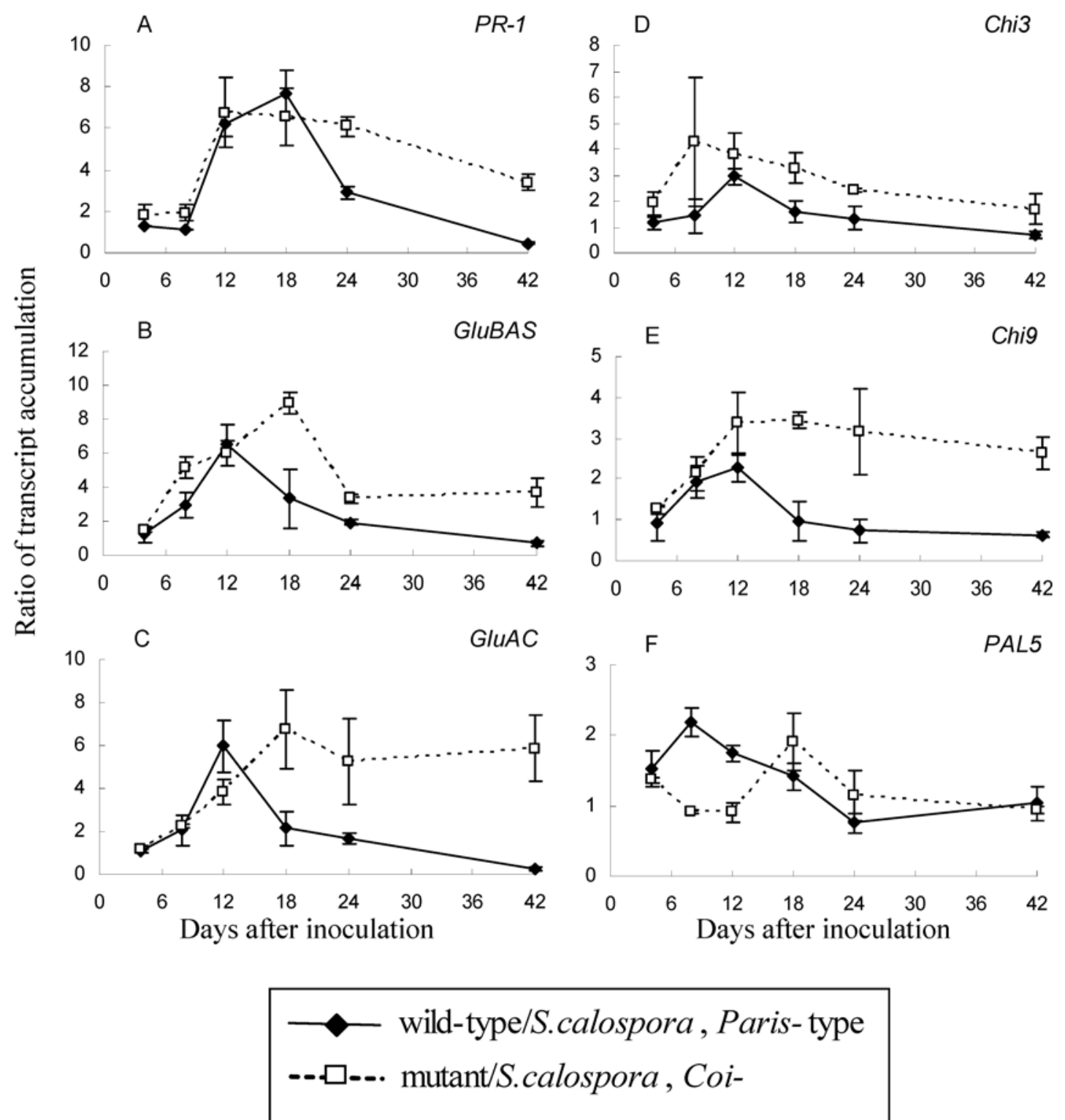

Fig. 3. Transcript accumulation upon inoculation with Scutellospora calospora of wild-type tomato (Paris-AM) and rmc mutant (Coi ${ }^{-}$phenotype). The panels show the ratio of mRNA from inoculated and mock-inoculated roots (i.e., a ratio of 1 indicates no difference between inoculated and mockinoculated plants). Values are means and standard errors of means of data from three separate pots of plants at each time point. 
3A, B, C, and E). In contrast, Chi3 mRNA accumulation was similar to that in the wild type, whereas PAL5 mRNA accumulated transiently but was delayed compared with the wild type (Fig. 3D and F). Furthermore, a strong defense response to invasion of the mutant by $S$. calospora was also indicated by an enhanced autofluorescence at the site of penetration, probably as the result of accumulation of phenolics.

G. intraradices, showing a $\mathrm{Pen}^{-}$phenotype on the $r m c \mathrm{mu}-$ tant with a very low frequency of epidermal penetration and colonization, did not induce the plant defense response to any significant level in relation to mock-inoculated control plants (Fig. 4). In contrast, with Glomus sp. WFVAM23 (Myc ${ }^{+}$; abnormal interaction at the epidermis, followed by normal although slower Arum-type cortical colonization) a three- to fourfold increase in GluBAS and Chi9 mRNA accumulation was observed between 8 and 24 days, compared with mockinoculated plants (Fig. 5B and E). For $P R-1$ and GluAC, no substantial increases in gene expression were found, whereas PAL5 and Chi3 mRNAs increased transiently, the former early between 8 and 12 days (Fig. 5F), the latter delayed as compared with the wild type (Fig. 5D and F).

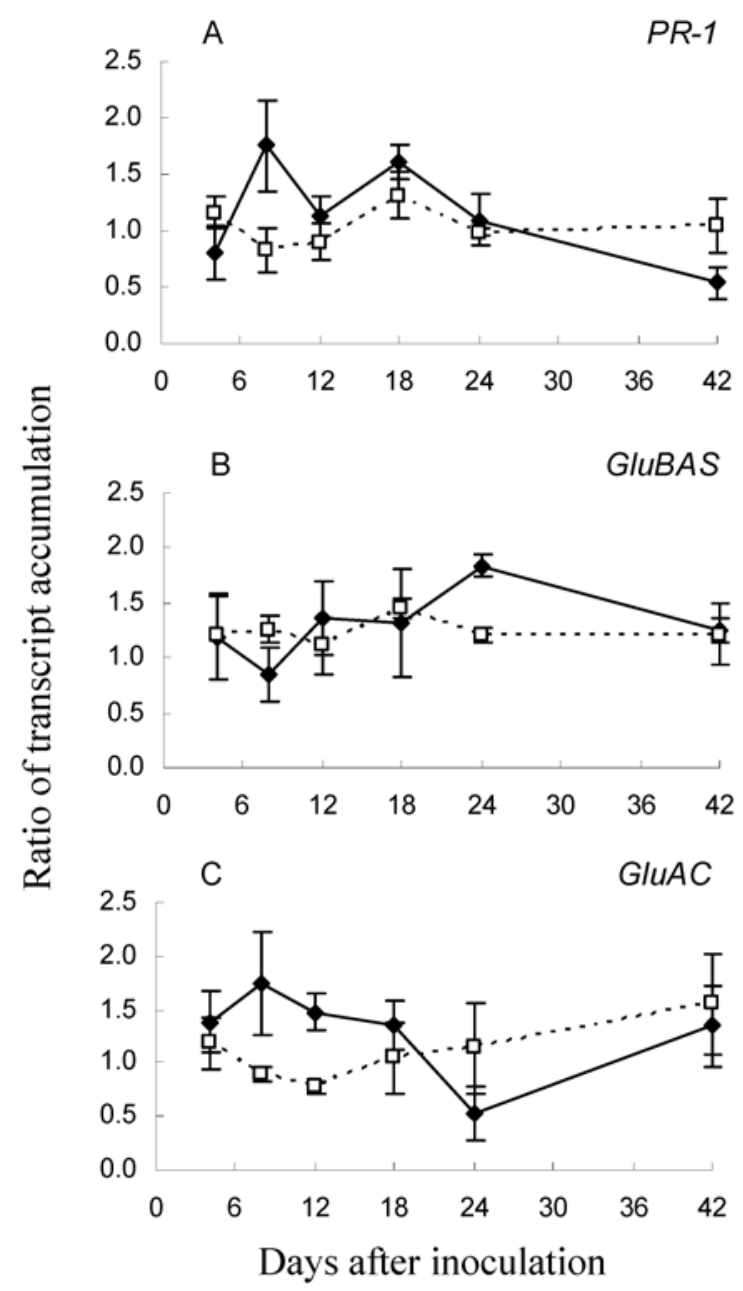

\section{DISCUSSION}

The interactions of six different AM fungi with tomato wildtype plants and with a near-isogenic mutant showing reduced mycorrhizal colonization $(r m c)$ provided the possibility to study different colonization patterns as well as different mutant phenotypes in a single plant species. Both major AM morphotypes (Arum and Paris types) are formed by different fungal species in wild-type tomato roots (Cavagnaro et al. 2001), and three different mutant phenotypes $\left(\mathrm{Pen}^{-}, \mathrm{Coi}^{-}, \mathrm{Myc}^{+}\right)$were obtained in roots of the $r m c$ mutant (Gao et al. 2001). The occurrence of these morphological differences prompted the question as to whether the plant defense response may be causally involved.

Wild-type tomatoes revealed substantial differences in the expression of defense-related genes between associations involving six different AM fungi, extending the observations of Pozo and associates (1999), who showed differential accumulation of glucanases in tomato depending on whether roots were colonized by $G$. mosseae or $G$. intraradices. These findings demonstrate that diversity in interactions between plants and different AM fungi includes defense-related gene expres-
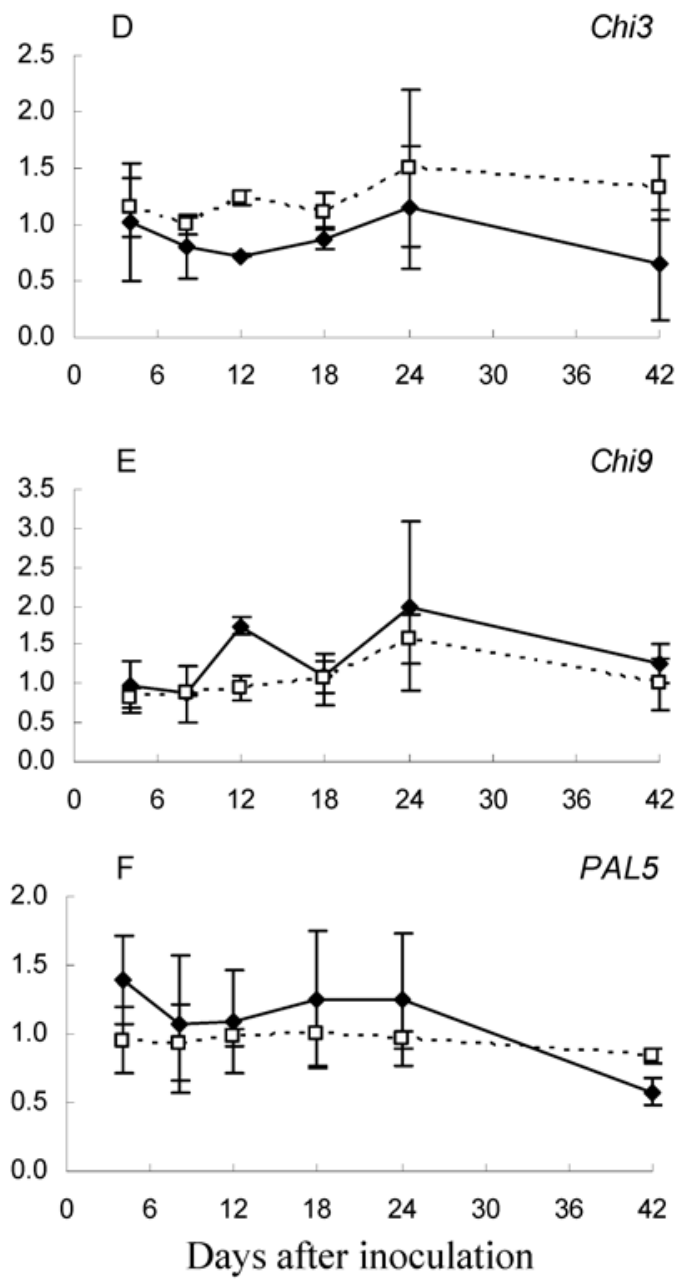

\section{$\longrightarrow$ wild-type/G.intraradices, Arum -type \\ --- $\square$-.. mutant/G.intraradices, Pen-}

Fig. 4. Transcript accumulation upon inoculation with Glomus intraradices of wild-type tomato (Arum-AM) and $r m c$ mutant $^{\left(P e n^{-}\right.}$phenotype). The panels show the ratio of mRNA from inoculated and mock-inoculated roots (i.e., a ratio of 1 indicates no difference between inoculated and mock-inoculated plants). Values are means and standard errors of means of data from three separate pots of plants at each time point. 
sion, as well as colonization morphology, growth, and $\mathrm{P}$ uptake (including associated gene expression) (Burleigh et al. 2002; Cavagnaro et al. 2001; Smith et al. 2003, 2004).

There was an indication that expression of some of the defense-related genes was different between Arum- and Paristype AM interactions. As demonstrated previously for the Arum-type AM in Medicago truncatula, Glycine max, Pisum sativum, and Nicotiana tabacum colonized by several different fungi (David et al. 1998; Harrison and Dixon 1993, 1994; Lambais and Mehdy 1996; Ruiz-Lozano et al. 1999), this AM morphotype was associated with relatively small changes in transcript accumulation in tomato roots colonized by $G$. intraradices, G. mosseae, and Glomus sp. WFVAM23. In contrast, the Paris-type interaction with $S$. calospora was accompanied by a much stronger defense response, with the expression, in particular, of PR-1 and both glucanases increased six- to eightfold in comparison with mock-inoculated control plants. The more pronounced accumulation of defense-related mRNAs in tomato interacting with other fungi forming Paris-type AM (Gigaspora margarita and G. coronatum) and the weak re- sponse upon colonization with fungi forming Arum-type AM may, therefore, represent a general phenomenon, but more work with a wider range of fungi will be required to confirm this correlation.

The cause of the stronger elicitation of defense reactions in Paris-type than in Arum-type AM may lie in the differences in fungal growth. Whereas Paris-type AM is associated with frequent penetration of cell walls by the fungus growing from cell to cell in the root cortex, these direct penetration events are relatively rare in Arum-type interactions, occurring only when single branch hyphae penetrate cortical cells to form arbuscules. The process of wall penetration is likely to involve hydrolytic enzymes (Garcia-Romera et al. 1990, 1991), which may release cell wall fragments capable of acting as endogenous elicitors (Garcia-Garrido and Ocampo 2002; Harrison 1999; Heath 2000) that would therefore be expected to be higher in Paris-AM.

Despite the differences in gene expression between Arumand Paris-type AM, the extent of tomato root colonization was as high with S. calospora (Paris-type AM) as with G. intraradi-

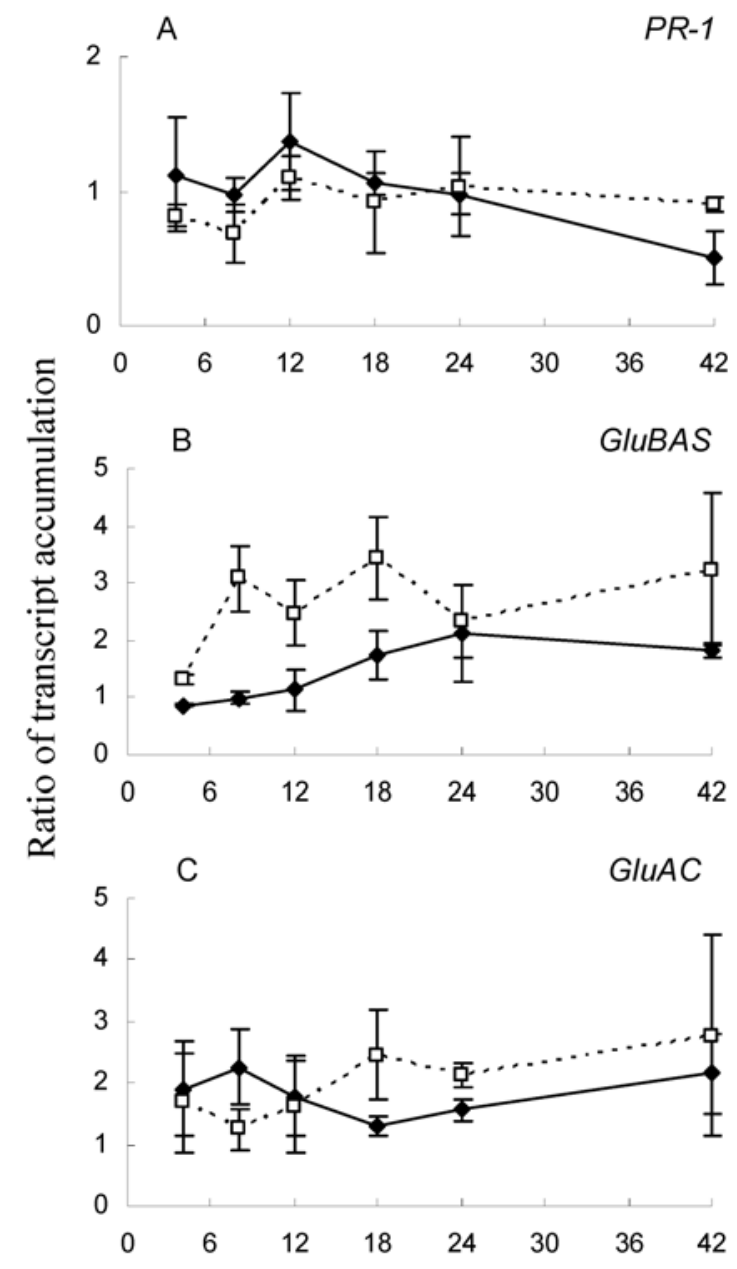

Days after inoculation
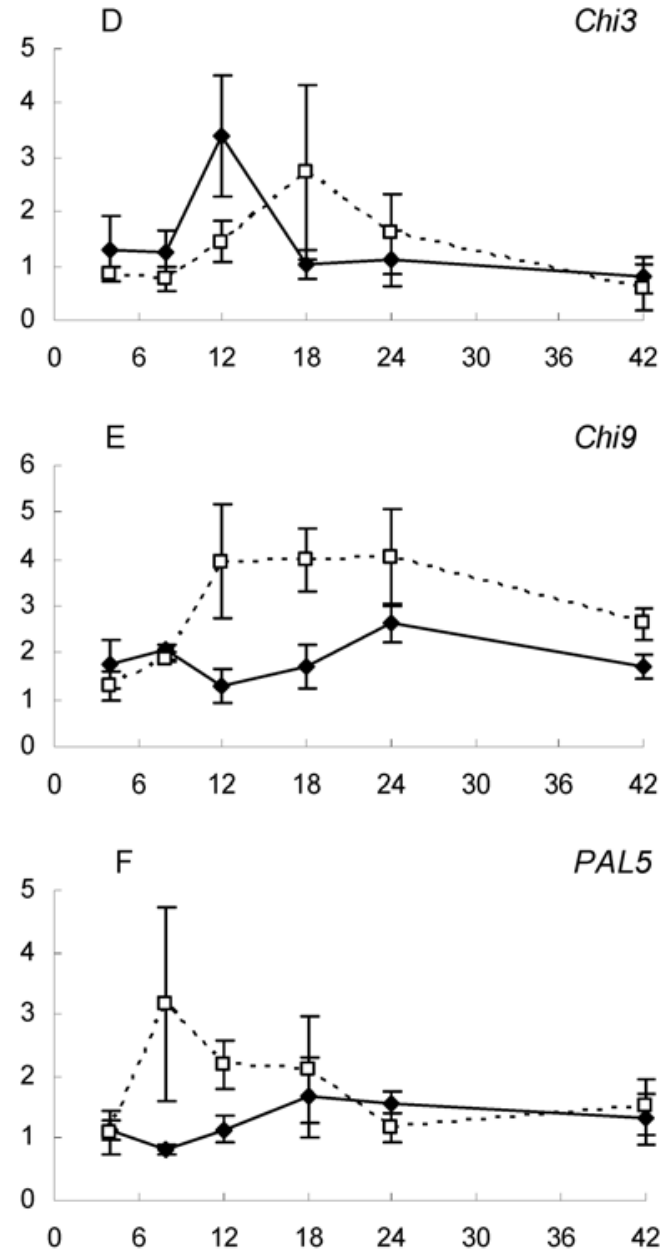

Days after inoculation

$$
\begin{aligned}
& \longrightarrow \text { wild-type/GS. WFVAM23, Arum -type } \\
& -\square \text {-.. mutant/GS. WFVAM23, Myc }+
\end{aligned}
$$

Fig. 5. Transcript accumulation upon inoculation with Glomus sp. WFVAM23 of wild-type tomato (Arum-AM) and $r m c$ mutant (Myc ${ }^{+}$phenotype). The panels show the ratio of mRNA from inoculated and mock-inoculated roots (i.e., a ratio of 1 indicates no difference between inoculated and mockinoculated plants). Values are means and standard errors of means of data from three separate pots of plants at each time point. 
ces and Glomus sp. WFVAM23 (Arum-type AM). This lack of correlation in the same plant species suggests that expression of defense-related genes to the levels observed does not reduce AM colonization in the tomato Paris-type interactions (relative to Arum-types) and, conversely, that nontriggering or suppression of the defense response in Arum-type interactions may not be essential for successful mycorrhizal colonization. Some previous work, all on Arum-type AM, also supports this conclusion. Formation of appressoria by G. mosseae on roots of both wild-type $P$. sativum and P2 mutant was positively correlated with expression of the defense-related gene pI 106, but mycorrhiza formation in the wild-type proceeded normally (RuizLozano et al. 1999). Recent transcript profiling in the Arumtype $M$. truncatula-G. intraradices interaction identified a group of plant stress and defense-related genes that show a transient increase in expression in the early stages of AM colonization, followed by a decrease (Liu et al. 2003). This is in line with previous work showing that either relatively low or transient defense-related reactions, or both, in M. sativa, M. truncatula, and $P$. sativum were associated with but did not prevent colonization by AM fungi (Harrison and Dixon 1993; Ruiz-Lozano et al. 1999; Volpin et al. 1994). Various alternative roles for defenserelated compounds in AM symbioses have been suggested, such as metabolic regulation by AM-induced flavonoids (Harrison and Dixon 1994) and cleaving of elicitors originating in the chitinous walls of the fungi by chitinases, which might actually reduce defense responses (Salzer et al. 2000). Additionally, the roles of defense-related compounds in mycorrhiza-induced protection from pathogens has been suggested (Cordier et al. 1998; Pozo et al. 1999).

Our results also show common features with previous work on mycorrhizal mutants, some of which have implicated defense responses in the restriction of fungal colonization. In mutant tomato, G. intraradices ( $\mathrm{Pen}^{-}$phenotype) remained largely on the root surface, and the generally low defense reactions were consistent with very few penetration events. Glomus sp. WFVAM23 $\left(\mathrm{Myc}^{+}\right)$formed highly branched and swollen appressorium-like structures on the root epidermis, a surface interaction very similar to that between a mutant of $M$. sativa and G. versiforme (Bradbury et al. 1991, 1993). The $M$. sativa interaction was blocked at this stage and was associated with relative increases in transcript levels of PAL, chalcone synthase, and isoflavone reductase, as compared with the wildtype interaction (Harrison and Dixon 1993). In contrast, Glomus sp. WFVAM23 was subsequently able to penetrate mutant tomato roots and to form a functionally normal mycorrhiza in the cortex, associated with a decline to the levels of transcripts seen in typical Arum-type interactions of the wild type. S. calospora, which is restricted to the epidermis and hypodermis of $r m c$ roots ( $\mathrm{Coi}^{-}$phenotype), induced strong and sustained expression of defense-related genes. The production of strongly autofluorescent material at sites of attempted penetration is similar to the response of the P2 mutant of pea (Gollotte et al. 1993). Thus, there was no uniform response in mutant as opposed to wild-type tomato, and again, the strength of the response varied with the degree of cellular penetration. The differences in response may therefore represent a side effect of the abnormal mode of fungal development in the mutant rather than a mechanism to control fungal colonization. We predict that the pmi mutants in tomato (M161 and M20) (David-Schwartz et al. 2001, 2003) would not, like $G$. intraradices, show marked defense responses. The present results therefore add weight to previous data indicating that products of defense-related genes do not play an important role in restricting fungal growth during mycorrhiza formation (Harrison and Dixon 1993; Ruiz-Lozano et al. 1999; Vierheilig et al. 1993, 1995), and there is no clear indication that the dif- ferent mutant phenotypes correlate with the expression of any of the defense-related genes analyzed. Rather, it appears likely that AM fungal colonization of mycorrhiza-defective mutants is blocked by events leading to either the formation of cell wall appositions (Douds et al. 1998; Gollotte et al. 1993; RuizLozano et al. 1999) or to localized cell death (Bonfante et al. 2000), although the molecular basis of triggering these responses remains unknown.

Previous investigations of AM interactions with mycorrhizadefective mutant plants have utilized one or a few fungi, and none have revealed the major phenotypic variations reported for tomato (Cavagnaro et al. 2001; Gao et al. 2001). The differences observed in the interaction between the $r m c$ mutant and different AM fungi revealed a level of specificity in plantfungus interactions that was not apparent in the wild type. This is particularly surprising, because the recessive nature of the mycorrhiza-defective mutations implies loss of function, which might be presumed to exclude all AM fungi in a similar way. Comparison with the recessive mlo mutants, which prevent powdery mildew infection in barley (Hordeum vulgare), may be revealing (Gianinazzi-Pearson et al. 1996; Harrison 1999). Wild-type $M L O$ is a negative regulator of the host defense response (Bueschges et al. 1997; Piffanelli et al. 2002) and is required for establishing the compatible interaction with the biotrophic fungus Blumeria graminis but not with the necrotrophs Magnaporthe grisea, Bipolaris sorokiniana (Kumar et al. 2001), or Rhynchosporium secalis (W. Knogge and P. Schulze-Lefert, unpublished results). Wild-type $R M C$ may act in a similar way, thus leading to the recognition of a mutualistic partner and enabling AM symbiosis to occur. The $r m c$ mutant allele, like the mlo mutants, may function in restricting penetration of host cell walls and hence to failure of establishment of sites of nutrient transfer. The recent identification of a receptor-like protein kinase (RLK) that is essential for establishment of AM symbiosis in Lotus (Stracke et al. 2002) confirms the importance of recognition in normal plant-AM fungus interactions. Polymorphisms in extracellular domains of orthologues of this RLK in different plant species suggest the possibility of different plant recognition specificities (Kistner and Parniske 2002). The different mutant phenotypes observed in tomato $\left(\mathrm{Pen}^{-}, \mathrm{Coi}^{-}, \mathrm{Myc}^{+}\right.$) also suggest the involvement of one or more fungal factors that may vary in the different AM fungal species and that trigger to differing extents the activation of exclusion mechanisms in conjunction with the $r m c$ protein. This hypothesis might provide a lead into understanding the mechanisms underlying the selectivity in choice of partners among plants and fungi that is increasingly being shown to operate in the field (Helgason et al. 2002) and into understanding diversity in function in different AM symbioses (Burleigh et al. 2002; Smith et al. 2003, 2004).

\section{MATERIALS AND METHODS}

\section{Plant material and fungal species.}

Plants used were a wild-type line of tomato (Lycopersicon esculentum Mill. cv. Rio-Grande), designated 76R, and a 76Rderived mutant with reduced mycorrhizal colonization $(\mathrm{rmc})$ (Barker et al. 1998). Leek (Allium porrum L. cv. Vertina) was used as nurse plant. Seeds of both species were surface-sterilized (4\% sodium hypochlorite, $15 \mathrm{~min}$ ), were rinsed in sterile reverse osmosis (RO) water, and were germinated on moist filter paper for 2 days prior to transplanting.

The species of AM fungi were $G$. intraradices Schenck and Smith (DAOM 181602), G. mosseae (Nicholson \& Gerdemann) Gerdemann and Trappe (NBR4-1), G. coronatum Giovannetti (WUM16), Glomus sp. WFVAM23 (Waite fungal culture collection, The University of Adelaide; formerly referred 
to as G. versiforme (Daniels \& Trappe) Berch), Gigaspora margarita Becker and Hall (obtained prior to the establishment of the Banque Europeen des Glomales), and Scutellospora calospora (Nicolson \& Gerdemann) Walker \& Sanders (WUM 12(2)). Fungal inocula were prepared in pot cultures of Trifolium subterraneum L. cv. Mt Barker, as previously described (Gao et al. 2001). The inoculum was composed of spores, dried roots, and soil. Control pots received mock inoculum from pot cultures of the same plant species grown without any AM fungi.

\section{Inoculation and plant growth.}

To produce near-synchronous and rapid mycorrhizal colonization and to avoid potential problems caused by the differences in inoculum potential between fungal species, the "nurse pot" system (Rosewarne et al. 1997) with leek (Allium porrum) as nurse plant was used for fungal inoculation (Gao et al. 2001).

\section{Harvest and assessment of fungal colonization.}

At the indicated times after transplantation into the nurse pots, plants were harvested, shaken free of soil, were thoroughly washed with water, and were blotted dry. After careful inspection for occurrence of any disease symptoms, roots were separated from shoots, and root samples from each pot were bulked. Before freezing of the roots with liquid nitrogen and storage at $-80^{\circ} \mathrm{C}$, random samples were taken to assess mycorrhizal colonization, as previously described (Gao et al. 2001). Laser scanning confocal microscopy was used in order to monitor the cell wall modifications of the root epidermis during colonization by $S$. calospora (Barker et al. 1998; Gao et al. 2001). In this investigation, the wavelengths used were $488 / 510 \mathrm{~nm}$ excitation and 522/532 $\mathrm{nm}$ emission.

\section{Genes and gene probes.}

The plant defense response was investigated by Northern analysis, using cDNA probes of six defense-related genes from tomato. The genes chosen represent five PR proteins and PAL (Table 2). Plasmids containing cDNA fragments of $P R-1$ (PR-P6), GluBAS, GluAC, Chi3, or Chi9 were provided by J. van Kan, Wageningen Agricultural University. A PAL5 cDNA cloned into the phage M13mp18 (Lee et al. 1992) was provided by J. Robb, University of Guelph, Canada. For maintenance and easy manipulation of this clone, the insert was first amplified with polymerase chain reaction (PCR), using pUCM13 forward or reverse primers (Promega, Annandale, NSW, Australia), following the PCR method described by Delp and associates (2000). The PCR product of the PAL5 cDNA fragment was ligated into a pGEM-T Easy vector, which was then transformed into E. coli JM109 (Promega), following the supplier's protocol.

A fragment of 18s rDNA from tomato was cloned by PCR using 18s rDNA-specific primers NS1 and NS21 (White et al. 1990; Simon et al. 1992), as described below. This fragment was used for normalization of RNA loading and transfer to the nylon membrane and for normalization of transcript levels of targeted genes. Total RNAs from nonmycorrhizal tomato roots were isolated using an RNeasy plant mini kit (Qiagen, Clifton Hill, Victoria, Australia). Total RNA (approximately $1 \mu \mathrm{g}$ ) was reverse-transcribed into cDNA that was amplified by PCR, using methods adapted from Delp and associates (2000). The PCR product was purified using QIAEX II agarose gel extraction kit (Qiagen) and was ligated into a pGEM-T Easy vector and transformed into E. coli MJ109 (Promega). The putative 18 s cDNA fragment was sequenced using a 373 XL DNA sequencer (Applied Biosystems, Foster City, CA, U.S.A.). Sequences were analyzed using Sequencing Analysis version
3.4.1 (Applied Biosystems). Sequence assembly and analysis used SeqED software (Applied Biosystems). Subsequent sequence was confirmed by comparison with other 18s rDNA sequences available in GenBank (results not shown).

\section{mRNA hybridization analysis.}

cDNA probes used for the Northern analysis were prepared as follows. Plasmid DNA was isolated using a NucleoSpin Plus plasmid miniprep kit (Clontech, BD Australia, North Ryde, Australia), following the supplier's protocol and the five PR protein cDNAs were digested with EcoRI and XhoI (Promega, Annandale, NSW, Australia); PAL5 and 18s cDNA were digested only with EcoRI (Promega). The cDNA fragments were isolated on agarose gels, were excised under UV light, and were purified using QIAEX II agarose gel extraction kit (Qiagen). The Chi9 cDNA yielded two fragments (approximately 860 and $348 \mathrm{bp}$ ), and the 860-bp fragment was chosen as the probe to achieve higher signal and hybridization specificity. The purified cDNA inserts were labeled with $\alpha-{ }^{32} \mathrm{P}$ using a Ready To-Go DNA labeling beads (-CTP) kit (Amersham Pharmacia Biotech, Uppsala, Sweden), following the manufacturer's instructions. After incubating the sample for $30 \mathrm{~min}$ at $37^{\circ} \mathrm{C}$, the unincorporated nucleotides were removed, using the NucleoSpin Plus column (Clontech).

For Northern hybridization analysis, total RNA was isolated from tomato roots using a FastRNA Kit-Green (Qbiogene Inc., Carlsbad, CA, U.S.A.) and was treated with RNase-free DNase (Qiagen) to remove the contaminant DNA, following the supplier's protocol. RNA samples (approximately $10 \mu \mathrm{g}$ ) were separated by electrophoresis in $3.4 \%$ formaldehyde gels and were blotted onto nylon membranes (Hybond- $\mathrm{H}^{+}$; Amersham Pharmacia Biotech), using standard methods (Sambrook et al. 1989). From each treatment, three duplicate membranes were prepared with the same RNA and were used for hybridization with different cDNA probes. Hybridization was carried out at $42^{\circ} \mathrm{C}$ for 16 to $40 \mathrm{~h}$ in a hybridization buffer containing $50 \%$ formamide, $5 \times \mathrm{SSPE}(1 \times \mathrm{SSPE}$ is $0.18 \mathrm{M} \mathrm{NaCl}, 10 \mathrm{mM}$ $\mathrm{NaPO}_{4}$, and $1 \mathrm{mM}$ EDTA [pH 7.7]), 2× Denhardt's reagent, $0.1 \%$ sodium dodecyl sulfate (SDS), and labeled cDNA probe (Sambrook et al. 1989). After completion of the hybridization, the membrane was rinsed three times in $2 \times \mathrm{SSC}(1 \times \mathrm{SSC}$ is $0.15 \mathrm{M} \mathrm{NaCl}$ plus $0.015 \mathrm{M}$ sodium citrate) and $0.1 \% \mathrm{SDS}$ at room temperature and once each in $2 \times, 1 \times$, or $0.5 \times$ SSC and $0.1 \%$ SDS solutions (depending upon the abundance of mRNAs in the roots of the tomato plants) at $65^{\circ} \mathrm{C}$ for $20 \mathrm{~min}$. Subsequently, membranes were exposed to a Storage Phosphor Screen (Molecular Dynamics, Amersham Biosciences, Castle Hill, Australia) for $1 \mathrm{~h}$ to a few days, depending on the abundance of the mRNA. Images were captured using a phosphorimager scanner (1995 version 4.00; Molecular Dynamics) and were analyzed using the ImageQuaNT V4.2 package (Molecular Dynamics). After completion of the analysis, the probe was removed from the hybridized membrane using a stripping solution $(1 \%$ [wt/vol] SDS, $0.1 \times \mathrm{SSC}$, and $40 \mathrm{mM}$ Tris-Cl, $\mathrm{pH}$ 7.6), and the membranes were reprobed up to three times. Northern analysis was carried out separately on RNAs from root samples generated in the three replicate pots. Transcript levels of genes were normalized based on the amount of 18s rRNA in the membranes. The effect of fungal colonization on mRNA accumulation was expressed as the ratio of mRNA in the inoculated plants to that in mock-inoculated plants.

\section{Statistical analysis.}

Fungal colonization and mRNA levels were analyzed statistically using ANOVA, Genstat 5 release 4.1, fourth edition (1998), Lawes Agricultural Trust (IACR Rothamsted, U.K.). 
Means were separated using the least significant difference test at $5 \%$ level of probability.

\section{ACKNOWLEDGMENTS}

We would like to thank D. Miller for excellent technical support. L.-L. Gao acknowledges the receipt of an Adelaide International postgraduate research scholarship. The work was supported by the Australian Research Council and a University of Adelaide Small Grant. We are grateful to J. van Kan, Department of Phytopathology, Wageningen Agricultural University, Wageningen, The Netherlands and J. Robb, Department of Molecular Biology and Genetics, University of Guelph, Ontario, Canada, who made the cDNA clones available to us.

\section{LITERATURE CITED}

Barker, S. J., Duplessis, S., and Tagu, D. 2002. Application of genetic approaches for investigations of mycorrhizal symbioses. Plant Soil 244:85-95.

Barker, S. J., Stummer, B., Gao, L., Dispain, I., O'Connor, P. J., and Smith, S. E. 1998. A mutant in Lycopersicon esculentum Mill. with highly reduced VA mycorrhizal colonization: Isolation and preliminary characterisation. Plant J. 15:791-797.

Blilou, I., Ocampo, J. A., and Garcia-Garrido, J. M. 1999. Resistance of pea roots to endomycorrhizal fungus or Rhizobium correlates with enhanced levels of endogenous salicylic acid. J. Exp. Bot. 50:1663-1668.

Bonanomi, A., Wiemken, A., Boller, T., and Salzer, P. 2001. Local induction of a mycorrhiza-specific class III chitinase gene in cortical root cells of Medicago truncatula containing developing or mature arbuscules. Plant Biol. 3:194-199.

Bonfante, P., Genre, A., Faccio, A., Martini, I., Schauser, L., Stougaard, J., Webb, J., and Parniske, M. 2000. The Lotus japonicus LjSym4 gene is required for the successful symbiotic infection of root epidermal cells. Mol. Plant-Microbe Interact. 13:1109-1120.

Bradbury, S. M., Peterson, R. L., and Bowley, S. R. 1991. Interactions between three alfalfa nodulation genotypes and two Glomus species. New Phytol. 119:115-120.

Bradbury, S. M., Peterson, R. L., and Bowley, S. R. 1993. Further evidence for a correlation between nodulation genotypes in alfalfa (Medicago sativa L.) and mycorrhiza formation. New Phytol. 124:665-673.

Bueschges, R., Hollricher, K., Panstruga, R., Simons, G., Wolter, M., Frijters, A., van Daelen, R., van der Lee, T., Diergarde, P., Groenendijk, J., Topsch, S., Vos, P., Salamini, F., and Schulze-Lefert, P. 1997. The barley Mlo gene: A novel control element of plant pathogen resistance. Cell 88:695-705.

Burleigh, S. H., Cavagnaro, T. R., and Jakobsen, I. 2002. Functional diversity of arbuscular mycorrhizas extends to the expression of plant genes involved in P nutrition. J. Exp. Bot. 53:1-9.

Cavagnaro, T. R., Gao, L.-L., Smith, F. A., and Smith, S. E. 2001. Morphology of arbuscular mycorrhizas is influenced by fungal identity. New Phytol. 151:469-475.

Cordier, C., Pozo, M. J., Barea, J. M., Gianinazzi, S., and GianinazziPearson, V. 1998. Cell defense responses associated with localized and systemic resistance to Phytophthora parasitica induced in tomato by an arbuscular mycorrhizal fungus. Mol. Plant-Microbe Interact. 11:10171028.

Danhash, N., Wagemakers, C. A. M., van Kan, J. A. L., and de Wit, P. J. G. M. 1993. Molecular characterisation of four chitinase cDNAs obtained from Cladosporium fulvum-infected tomato. Plant Mol. Biol. 22:1017-1029.

David, R., Itzhak, H., Ginsberg, I., Gafni, Y., Galili, G., and Kapulnik, Y. 1998. Suppression of tobacco basic chitinase gene expression in response to colonization by the arbuscular mycorrhizal fungus Glomus intraradices. Mol. Plant-Microbe Interact. 11:489-497.

David-Schwartz, R., Badani, H., Smadar, W., Levy, A. A., Galili, G., and Kapulnik, Y. 2001. Identification of a novel genetically controlled step in mycorrhizal colonization: Plant resistance to infection by fungal spores but not extra-radical hyphae. Plant J. 27:561-569.

David-Schwartz, R., Gadkar, V., Wininger, S., Bendov, R., Galili, G., Levy, A. A., and Kapulnik, Y. 2003. Isolation of a premycorrhizal infection (pmi2) mutant of tomato, resistant to arbuscular mycorrhizal fungal colonization. Mol. Plant-Microbe Interact. 16:382-388.

Delp, G., Smith, S. E., and Barker, S. J. 2000. Isolation by differential display of three partial cDNAs potentially coding for proteins from the VA mycorrhizal Glomus intraradices. Mycol. Res. 104:293-300.

Douds, D. D. J., Galvez, L., Bécard, G., and Kapulnik, Y. 1998. Regulation of arbuscular mycorrhizal development by plant host and fungus species in alfalfa. New Phytol. 138:27-35.
Dumas-Gaudot, E., Asselin, A., Gianinazzi-Pearson, V., Gollotte, A., and Gianinazzi, S. 1994. Chitinase isoforms in roots of various pea genotypes infected with arbuscular mycorrhizal fungi. Plant Sci. 99:27-37.

Gao, L.-L., Delp, G., and Smith, S. E. 2001. Colonization patterns in a mycorrhiza-defective mutant tomato vary with different arbuscularmycorrhizal fungi. New Phytol. 151:477-491.

Garcia-Garrido, J. M., and Ocampo, J. A. 2002. Regulation of the plant defence response in arbuscular mycorrhizal symbiosis. J. Exp. Bot. 53:1377-1386.

Garcia-Romera, I., Garcia Garrido, J. M., and Ocampo, J. A. 1991. Pectolytic enzymes in the vesicular-arbuscular mycorrhizal fungus Glomus mosseae. FEMS (Fed. Eur. Microbiol. Soc.) Lett. 78:343-346.

Garcia-Romera, I., Garcia-Garrido, J. M., Martinez-Molina, E., and Ocampo, J. A. 1990. Possible influence of hydrolytic enzymes on vesicular-arbuscular mycorrhizal infections of alfalfa. Soil Biol. Biochem. 22:149-152.

Gianinazzi-Pearson, V. 1984. Host-fungus specificity, recognition and compatibility in mycorrhizae. Pages 225-253 in: Genes Involved in Microbe-Plant Interactions. D. P. S. Verma and T. H. Hohn, eds. Springer Verlag, Wien, Austria.

Gianinazzi-Pearson, V., Dumas-Gaudot, E., Gollotte, A., Tahiri-Alaoui, A. and Gianinazzi, S. 1996. Cellular and molecular defence-related roo responses to invasion by arbuscular mycorrhizal fungi. New Phytol. 133:45-57.

Gollotte, A., Gianinazzi-Pearson, V., Giovannetti, M., Sbrana, C., Avio, L., and Gianinazzi, S. 1993. Cellular localization and cytochemical probing of resistance reactions to arbuscular mycorrhizal fungi in the 'locus $a^{\prime}$ myc $^{-}$mutant of Pisum sativum L. Planta. 191:112-122.

Harrison, M. J. 1999. Molecular and cellular aspects of the arbuscular mycorrhizal symbiosis. Ann. Rev. Plant Physiol. Plant Mol. Biol. 50:361389.

Harrison, M. J., and Dixon, R. A. 1993. Isoflavonoid accumulation and expression of defense gene transcripts during the establishment of vesicular-arbuscular mycorrhizal associations in roots of Medicago truncatula. Mol. Plant-Microbe Interact. 6:643-654.

Harrison, M. J., and Dixon, R. A. 1994. Spatial patterns of expression of flavonoid/isoflavonoid pathway genes during interactions between roots of Medicago truncatula and the mycorrhizal fungus Glomus versiforme. Plant J. 6:9-20.

Heath, M. C. 2000. Nonhost resistance and nonspecific plant defenses. Curr. Opin. Plant Biol. 3:315-319.

Helgason, T., Merryweather, J. W., Denison, J., Wilson, P., Young, J. P. W., and Fitter, A. H. 2002. Selectivity and functional diversity in arbuscular mycorrhizas of co-occurring fungi and plants from a temperate deciduous woodland. J. Ecol. 90:371-384.

Kistner, C., and Parniske, M. 2002. Evolution of signal transduction in intracellular symbiosis. Trend Plant Sci. 7:511-518.

Kumar, J., Huckelhoven, R., Beckhove, U., Nagarajan, S., and Kogel, K. H. 2001. A compromised Mlo pathway affects the response of barley to the necrotrophic fungus Bipolaris sorokiniana (Teleomorph: Cochliobolus sativus) and its toxins. Phytopathology 91:127-133.

Lambais, M. R., and Mehdy, M. C. 1996. Soybean roots infected by Glomus intraradices strains differing in infectivity exhibit differential chitinase and $\beta$-1,3-glucanase expression. New Phytol. 134:531-538.

Lee, S.-W., Nazar, R. N., Powell, D. A., and Robb, J. 1992. Reduced PAL gene suppression in Verticillium-infected resistant tomatoes. Plant Mol. Biol. 18:345-352.

Liu, J. Y., Blaylock, L. A., Endre, G., Cho, J., Town, C. D., VandenBosch, K. A., and Harrison, M. J. 2003. Transcript profiling coupled with spatial expression analyses reveals genes involved in distinct developmental stages of an arbuscular mycorrhizal symbiosis. Plant Cell. 15:2106-2123.

Marsh, J. F., and Schultze, M. 2001. Analysis of arbuscular mycorrhizas using symbiosis-defective plant mutants. New Phytol. 150:252-532.

Morandi, D., Gollotte, A., and Camporota, P. 2002. Influence of an arbuscular mycorrhizal fungus in the interaction of a binucleate Rhizoctonia species with $\mathrm{Myc}^{+}$and $\mathrm{Myc}^{-}$pea roots. Mycorrhiza 12:97-102.

Newsham, K. K., Fitter, A. H., and Watkinson, A. R. 1995. Multifunctionality and biodiversity in arbuscular mycorrhizas. Trend Ecol. Evol. 10:407-411.

Peterson, R. L., and Guinel, F. C. 2000. The use of plant mutants to study regulation of colonisation by AM fungi. Pages 147-171 in: Arbuscular Mycorrhizas: Physiology and Function. Y. Kapulnik and D. D. J. Douds, eds. Kluwer Academic Publishers, Dordrecht, The Netherlands.

Piffanelli, P., Zhou, F. S., Casais, C., Orme, J., Jarosch, B., Schaffrath, U., Collins, N. C., Panstruga, R., and Schulze-Lefert, P. P. P. 2002. The barley MLO modulator of defense and cell death is responsive to biotic and abiotic stress stimuli. Plant Physiol. 129:1076-1085.

Pozo, M. J., Azcon Aguilar, C., Dumas Gaudot, E., and Barea, J. M. 1999. $\beta$-1,3-glucanase activities in tomato roots inoculated with arbuscular mycorrhizal fungi and/or Phytophthora parasitica and their possible in- 
volvement in bioprotection. Plant Sci. 141:149-157.

Rosewarne, G. M., Barker, S. J., and Smith, S. E. 1997. Production of near-synchronous fungal colonization in tomato for developmental and molecular analyses of mycorrhiza. Mycol. Res. 101:966-970.

Ruiz-Lozano, J. M., Roussel, H., Gianinazzi, S., and Gianinazzi-Pearson, V. 1999. Defense genes are differentially induced by a mycorrhizal fungus and Rhizobium sp. in wild-type and symbiosis-defective pea genotypes. Mol. Plant-Microbe Interact. 12:976-984.

Salzer, P., Bonanomi, A., Beyer, K., Vogeli-Lange, R., Aeschbacher, R. A., Lange, J., Weimken, A., Kim, D., Cook, D. R., and Boller, T. 2000. Differential expression of eight chitinase genes in Medicago truncatula roots during mycorrhiza formation, nodulation, and pathogen infection. Mol. Plant-Microbe Interact. 13:763-777.

Sambrook, J., Fritsch, E. F., and Maniatis, T. 1989. Molecular Cloning: A Laboratory Manual, 2nd ed. Cold Spring Harbor Laboratory Press, Cold Spring Harbor, NY, U.S.A.

Sanders, I. R. 2002. Specificity in the arbuscular mycorrhizal symbiosis. Pages 416-437 in: Mycorrhizal Ecology. M. G. A. Van Der Heijden and I. R. Sanders, eds. Springer Verlag, Berlin, Germany.

Simon, L., Lalonde, M., and Bruns, T. D. 1992. Specific amplification of $18 \mathrm{~S}$ fungal ribosomal genes from vesicular-arbuscular endomycorrhizal fungi colonizing roots. Appl. Env. Microbiol. 58:291-295.

Smith, F. A., and Smith, S. E. 1997. Structural diversity in (vesicular)-arbuscular mycorrhizal symbiosis. New Phytol. 137:373-388.

Smith, S. E., and Read, D. J. 1997. Mycorrhizal symbiosis, 2nd ed. Academic Press Ltd, London.

Smith, S. E., Smith, F. A., and Jakobsen, I. 2003. Mycorrhizal fungi can dominate phosphate supply to plants irrespective of growth responses. Plant Physiol. 133:16-20.
Smith, S. E., Smith, F. A., and Jakobsen, I. 2004. Functional diversity in arbuscular mycorrhizal (AM) symbioses: The contribution of the mycorrhizal $\mathrm{P}$ uptake pathway is not correlated with mycorrhizal responses in growth or total P uptake. New Phytol. 162:511-524.

Stracke, S., Kistner, C., Yoshida, S., Mulder, L., Sato, S., Kaneko, T., Tabata, S., Sandal, N., Stougaard, J., Szczyglowski, K., and Parniske, M. 2002. A plant receptor-like kinase required for both bacterial and fungal symbiosis. Nature 417:959-962.

van Kan, J. A. L., Joosten, M. H. A. J., and Wagemakers, C. A. M. 1992. Differential accumulation of mRNAs encoding extracellular and intracellular PR proteins in tomato induced by virulent and avirulent races of Cladosporium fulvum. Plant Mol. Biol. 20:513-527.

Vierheilig, H., Alt, M., Neuhaus, J. M., Boller, T., and Wiemken, A. 1993. Colonization of transgenic Nicotiana sylvestris plants, expressing different forms of Nicotiana tabacum chitinase, by the root pathogen Rhizoctonia solani and by the mycorrhizal symbiont Glomus mosseae. Mol. Plant-Microbe Interact. 6:261-264.

Vierheilig, H., Alt, M, Lange, J, Gut-Rella, M, Wiemken, A, Boller, T 1995. Colonization of transgenic tobacco constitutively expressing pathogenesis-related proteins by the vesicular-arbuscular mycorrhizal fungus Glomus mosseae. Appl. Env. Microbiol. 61:3031-3034.

Volpin, H., Elkind, Y., Okon, Y., and Kapulnik, Y. 1994. A vesicular-arbuscular mycorrhizal fungus (Glomus intraradix) induces a defense response in alfalfa roots. Plant Physiol. 104:683-689.

White, T. J., Bruns, T., Lee, S., and Taylor, J. 1990. Amplification and direct sequencing of fungal ribosomal RNA genes for phylogenetics. Pages 315-322 in: PCR Protocols. A Guide to Methods and Applications. M. A. Innis, D. H. Gelfaud, J. J. Sninsky, and T. J. White, eds. Academic Press, San Diego, U.S.A. 